\title{
TILL STRATIGRAPHY IN SOUTHERN AND WESTERN FINLAND
}

\author{
KEIJO NENONEN
}

NENONEN, KEIJO, 1992. Till stratigraphy in southern and western Finland. Bull. Geol. Soc. Finland 64, Part 2, 149-160.

This paper gives a review over the recent discoveries and results of Quaternary stratigraphical studies in southern and western Finland. The study of Quaternary stratigraphy has been very active and both Quaternary departments in Universities and Geological Survey of Finland as well as single geologists from Finland and abroad have contributed to the study of interglacial and interstadial stratigraphy this area. Main questions solved and to be solved is the relationship between the lithostratigraphy of last deglaciation and stratigraphy of earlier Pleistocene glacial i.e. Weichselian glaciations and Saalian glaciations. The active ice lobes during last deglaciation, their withdrawals and advances have deposited glaciofluvial and waterlain sediments which are covered by till formations. Ice lobes have eroded much of the »older»stratigraphy and information of the earlier Pleistocene glacial is fragmentary. Organic interglacial and interstadial sediments between till formations in Lapland and western Finland have made it possible to correlate till stratigraphy to larger areas and over national borders. Organic interglacial and interstadial sediments are so far missing from southern Finland.

One of the crucial questions to be solved is the glaciations of the Early Weichselian substage and their unknown extend to northern, western or southern Finland. The length of the probable ice free period between Saalian deglaciation and the first Weichselian ice advance after the Weichselian interstadials to Ostrobothnia is unknown. Recent discoveries of interglacial and interstadial sediments older than Eemian interglacial have erased questions of the uniformity of Saalian glaciation here up North and questions of climatic and hydrographic development under Holsteinian interglacial in southern and western Finland.

A synthesis is given of the Pleistocene stratigraphy in southern and western Finland. Stratigraphic work goes ahead very quickly and study of the deep depressions in bedrock and their thick Pleistocene sediments gives certainly more light to the Pleistocene development in southern and western Finland in the future. There is need for comprehensive Pleistocene stratotypes from the main glacial stratigraphy of Pleistocene glacial and lithostratigraphy of last deglaciation from southern and western Finland.

Key words: stratigraphy, till, deglaciation, glaciation, ice-marginal features, interglacial environment, interstadial environment Pleistocene, Finland.

Keijo Nenonen: Geological Survey of Finland P.O. Box 123770701 Kuopio, Finland

\section{Introduction}

Being situated in the middle of the area affected by the Scandinavian ice sheet (Fig. 1), southern and western Finland has been repeatedly scoured by the ice masses of Quaternary glaciations. The country has only a thin covering of unconsolidated, Quaternary deposits, with a mean depth of $6.7 \mathrm{~m}$. It has no complete stratigraphical profiles representing longer parts of the Quaternary period such as may found at or beyond the margins of the ice sheet, since the interglacial and interstadial organic deposits have for the most part been lost by subsequent glacial erosion. The till that accumulated during the various glaciations, and the glacigenic sediments remaining from the deglaciation phases, on the other hand, have proved more resistant and in many places have escaped 


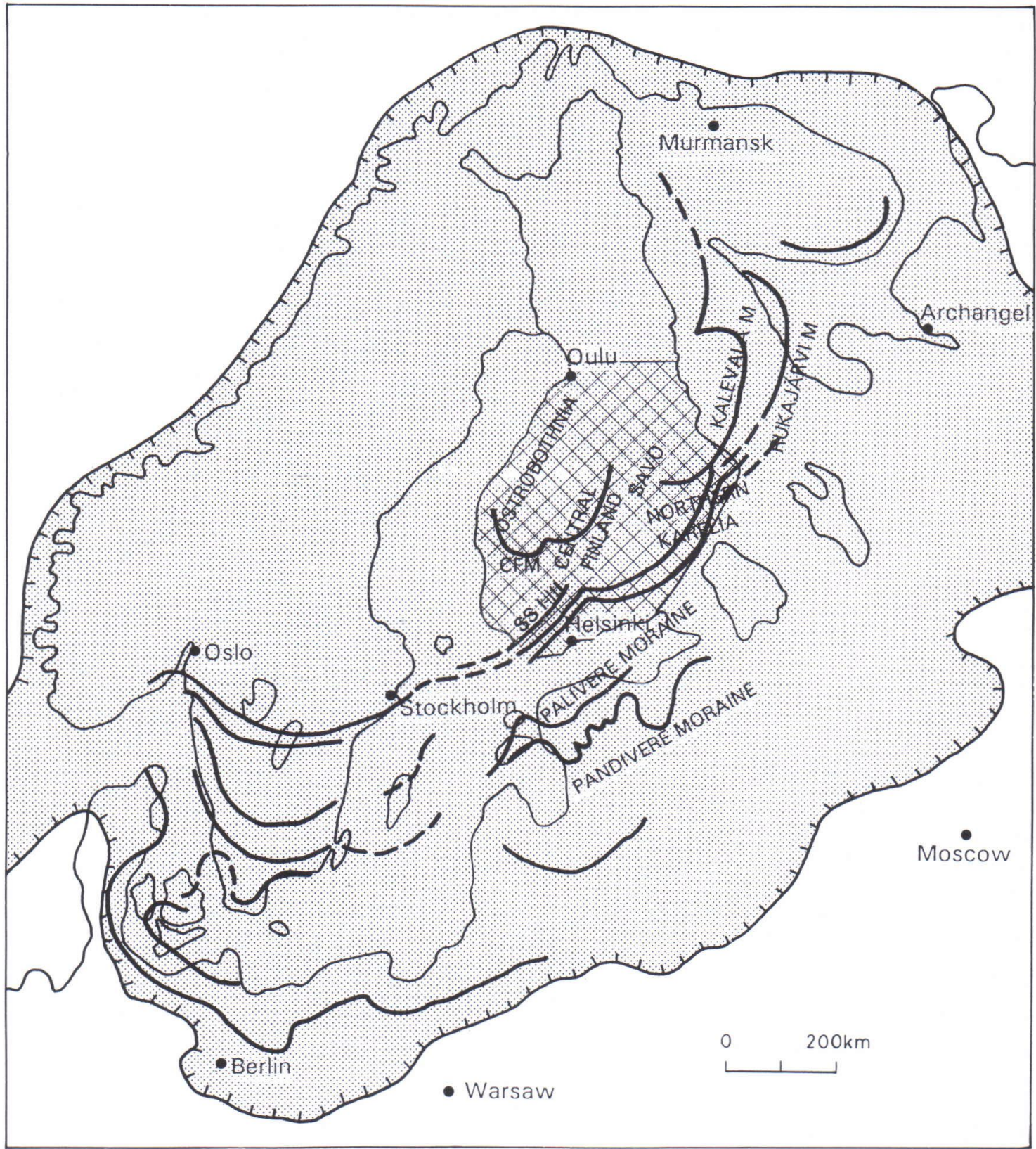

Fig. 1. The location of the study area of southern and western Finland in the centre of former Scandinavian ice sheet during maximum extent of Weichselian glaciation. Major end moraine zones are also marked.

later deformation. Thus the Quaternary stratigraphy of Finland is to a very great extent a matter of till stratigraphy.

In southern and western Finland the problems of till stratigraphy are following: Firstly in southern Finland during the deglaciation of Scandinavian ice sheet occurred a couple of major readvances of huge ice lobes. Salpausselkä endmoraines as 
SOUTH

SOUTHERN COAST
$500 \mathrm{KM}$

HÄME AND KARELIA
NORTH

CENTRAL FINLAND

OSTROBOTHNIA

\section{SALPAUSSELKÄ MORAINES (YOUNGER DRYAS)}

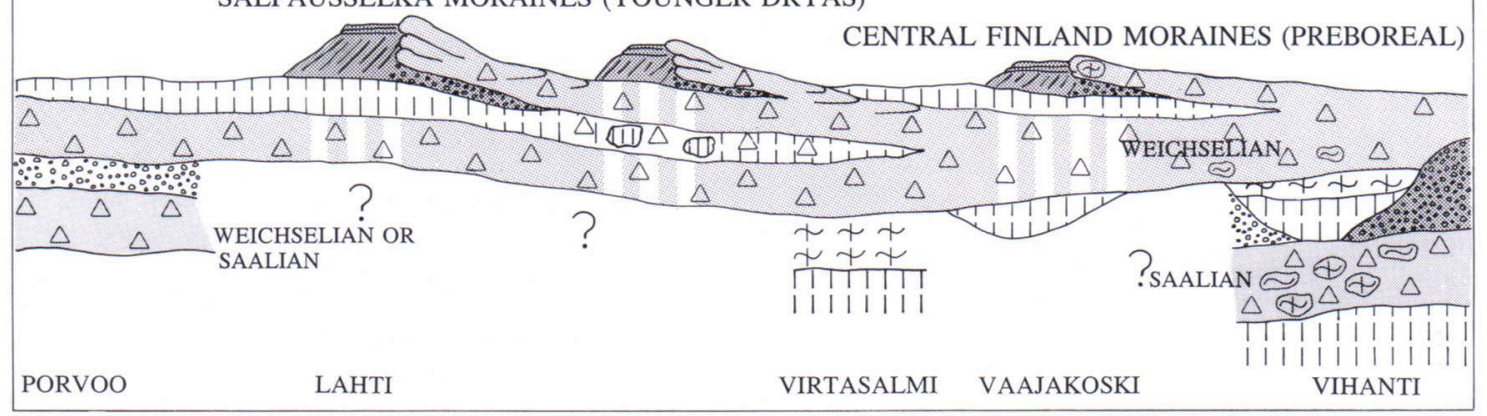

\section{IIII)} ice-marginal formation till covered esker

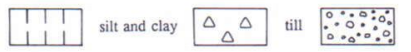
sand and gravel

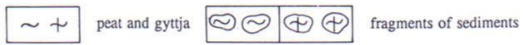

Fig. 2. Diagram of the relationship between endmoraines and till stratigraphy deposited by readvancing ice lobes in southern and western Finland.

well as central Finland ice marginal formation were formed along the edges of these ice lobes. Corresponding glacial events have eroded, deformed and covered earlier glacigenic deposits of Quaternary. Also dateable interglacial and interstadial deposits are so far missing from southern Finland (Fig. 2 ). Secondly in western Finland at Ostrobothnia submorainic interglacial and interstadial deposits are quite frequent, and they have made it possible to make preliminary dating and correlations of till stratigraphy to other parts of the North. A main question in western Finland is when the Scandinavian continental ice sheet reached Ostrobothnia during its growth toward glacial maximum.

\section{The area outside (S and E) the Salpausselkä moraines}

The southern coastal strip of Finland and a small area of North Karelia have two distinct till beds of which the uppermost was deposited by a NWSE ice flow. This direction is consistent throughout the area beyond the Salpausselkä end moraines, and coincides with the orientation of the youngest striae found in the area. The material involved is usually a brownish grey sandy till with a clay $(<0.002 \mathrm{~mm})$ content normally below $5 \%$. Sites in southern Finland located in bedrock depressions or in sheltered position with respect to the last ice flow direction usually also contain a highly compact, dark grey sandy - silty till beneath the younger till in stratigraphy. The lower till, which has a clay content of $10-15 \%$, generally shows a $\mathrm{N}-\mathrm{S}$ orientation consistent with that of the older striae in the area.

Raino \& Lahermo (1976, 1984) also describe an extremely well compacted silty till in southern Finland that would seem to correspond to the »older till» discussed above. Thin sand or gravel deposits (c. $1 \mathrm{~m}$ thick) are encountered here and there between the two till beds. This older compacted till is also fond in lumps of varying size within the younger till. No organic deposits have been discovered between till beds in southern Finland, although some interglacial or interstadial mammoth remains have been found in the till itself (Donner et al. 1979). The nearest sites where intervening organic sediments have appeared are in Estonia, where the Eemian interglacial deposits are covered by till bed (Liivrand 1984).

The glacial stratigraphy of Uusimaa province 
has been described by Bouchard et al. (1990) and Salonen \& Glückert (in press). According to Bouchard et al.(1990) the Siuntio Till Member, which is a silty till deposited by ice flowing from north to south and the lowermost member in the lithostratigraphy, represents the lodgement till formed during the Older Dryas stadial of the Weichsel glaciation, which deposited Palivere moraine in Estonia (Salonen \& Glückert, in press). The Espoo Till Member, which is the upper sandy till deposited by ice flowing from the northwest, represents the basal melt-out facies deposited during deglaciation, of the same glacier.

\section{The Salpausselkä Ice marginal zone}

The general stratigraphy in the Salpausselkä zone and its outside areas is two till beds of different ages separated by glaciofluvial gravel and sand deposits and by varve silt deposits. Some glaciofluvial formations are also to be found buried beneath the younger till. The youngest till bed was deposited in connection with a readvance, when the ice flow was directed in a radial manner towards the Salpausselkä ice marginal formations. This till is called »Salpausselkä readvance till».

Consistent evidence for this flow pattern is provided by the orientations of the youngest till, the youngest striae and the drumlins and eskers in the area (Hirvas \& Nenonen 1987, Kujansuu \& Nenonen 1987). In many places, e.g. around Vammala, Heinola and Rääkkylä, an older till bed has been encountered that was deposited at a time when the ice flow was from NW to SE, as also shown by the older striae in the area. This direction coincides with the youngest direction of glacial flow on the distal side of the Salpausselkä end moraines.

The varve sediments found in situ between the till beds indicate that the area was free of ice before the last glacial advance, when a vast ice lobe spread over the area. The margins of the lobe gave rise to the Salpausselkä marginal formations.

Similar observations of the phases of ice flow and glacial re-advance in the Salpausselkä zone have been made by many authors, including Repo
(1957), M. Okko (1962), Hyyppä (1966), Aartolahti (1972) and Rainio (1985). The situation described above suggests that the older till encountered in the Salpausselkä zone and within the area bounded by these formations was laid down during the same phase of ice flow as the younger till bed in the area outside ( $\mathrm{S}$ and $\mathrm{E}$ ) this zone.

\section{The Central Finland ice-marginal formation}

The last ice flow in the central Finland and Ostrobothnia radiated towards the Central Finland ice-marginal formation in the same manner as that directed towards the Salpausselkä zone (Fig. 3). Glaciofluvial sediments and an older till have been discovered beneath the till laid down during this Jyväskylä readvance (Ranio et al. 1986, Rainio 1991) in an area immediately adjacent to the marginal formation. Here too, the orientation of the older till and older striae coincides with that of the surface till and younger striae in the area beyond the marginal formation. It is thus concluded that the older till in the area behind the marginal formation must have been deposited during the ice flow that terminated at Salpausselkä, i.e. it is »Salpausselkä readvance till».

\section{Western Finland — Ostrobothnia}

The till stratigraphy of Ostrobothnia is considerably more complex than that of the areas discussed above, since large numbers of glaciofluvial deposits buried beneath till, superimposed till beds and silt, clay and organic deposits variously interpreted as interstadial or interglacial have been encountered, as described by Aario (1966), Ignatius \& Leskelä (1970), Niemelä \& Tynni (1979), Donner $(1983,1988)$ Eriksson et al. (1980), Forsström (1982, 1984), Forsström et al. (1987, 1988) and Aalto et al. (1983,1989) (Fig. 3).

There are also many occurrences of loose preglacial weathered bedrock in the area. Pollen and diatom evidence indicates that the great majority of the minerogenic and organic deposits found be- 


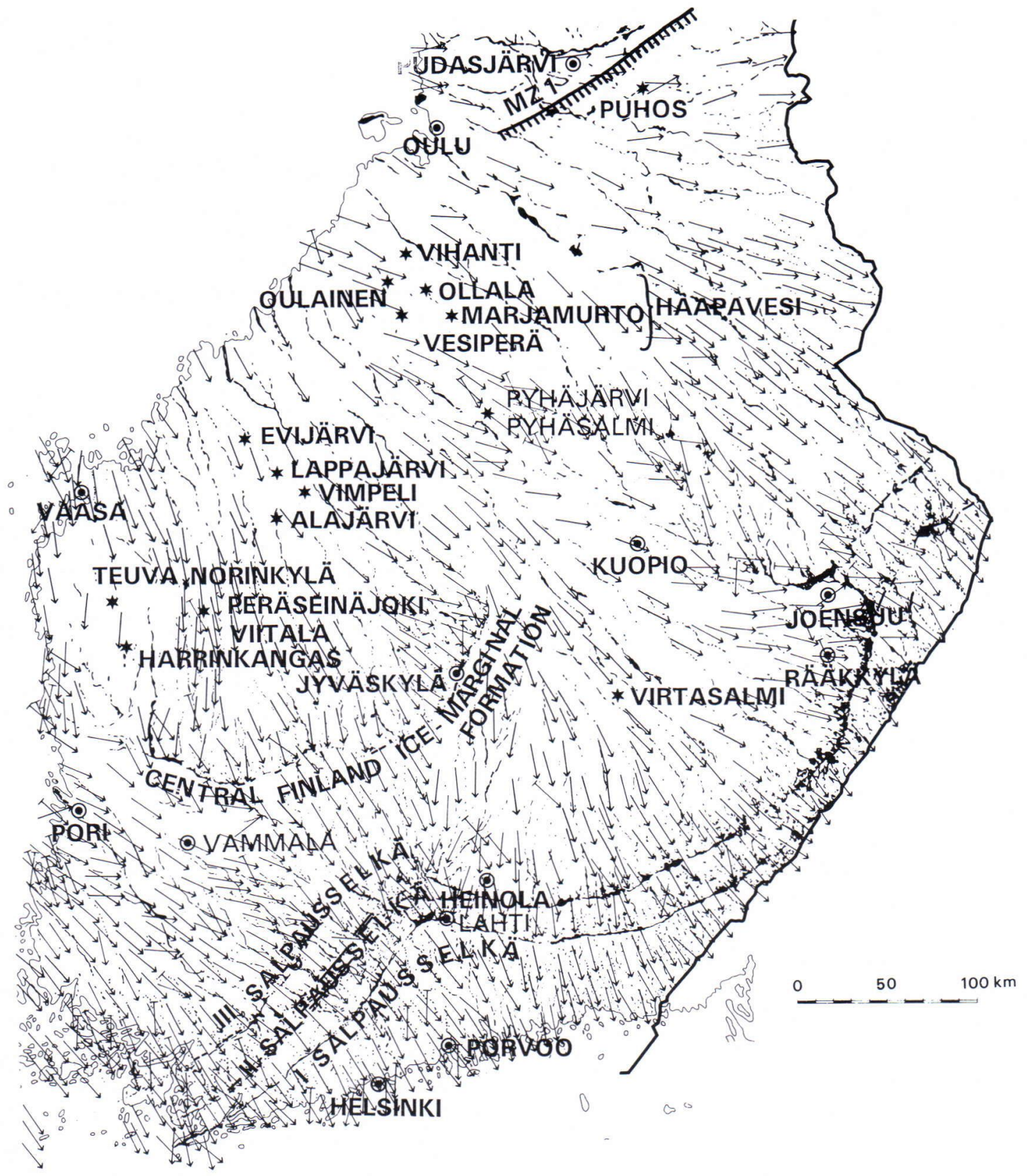

Figure 3. Location of interglacial- interstadial localities and geographic areas mentioned in the text. Base map, striations, eskers and ice-marginal formations (Geological Survey of Finland, Department of Quaternary Geology 1986). The probable EarlyWeichselian endmoraine MZ I at Pudasjärvi (Sutinen 1982,1992) is also marked.

neath till are interglacial, and efforts at radiocarbon dating have shown that they are invariably older than can be reliably estimated with that meth- od. These horizons are usually overlain by only one till bed, representing the youngest till in the area, or the organic material is in a secondary po- 
sition within the younger till or in glaciofluvial material lying beneath it.

The direction of glacial flow responsible for the deposition of the younger till in Ostrobothnia varies from $\mathrm{W}-\mathrm{E}$, around Vihanti, to $\mathrm{N}-\mathrm{S}$, around Seinäjoki, because the last ice flow in the course of deglaciation took place radially towards the edges of the ice lobe i.e. Central Finland ice marginal formation and its continuations

An older till has been identified beneath the younger till at sites close to Seinäjoki and Vimpeli and in the Haapavesi-Pyhäjärvi-Kiuruvesi area. This older till in Ostrobothnia would seem to have been quite consistently laid down in an ice flow running NW-SE over an extensive part of the region. Minerogenic sediments representing an ice-free phase are found under the younger till and between the younger and older till beds in the Seinäjoki and central Ostrobothnia.

For example about $0.5 \mathrm{~m}$ clay is found under a $3.5 \mathrm{~m}$ thick till bed at Peräseinäjoki Viitala. The silt contain a typical Eemian interglacial pollen flora and evidence of a fresh water stage in Bothnian Gulf before marine transgression (Nenonen et al. 1991, Grönlund 1991). Similar pollen and diatom assemblages have been observed in the younger till containing $10-20 \%$ clay of Peräseinäjoki area. It would thus seem that the finer fractions in the younger till derive from sediments laid down during the intervening ice-free period.

At Haapavesi in central Ostrobothnia, the presence of an in situ organic deposit between Weichselian and Saalian glacial deposits makes it possible to correlate the till stratigraphy (Fig. 4). A climate at least as warm as that prevailing during the postglacial climatic optimum is reflected by the pollen flora of the sediments between the till beds (Fig. 4a.)(Nenonen 1986, Nenonen et al. 1991). The pollen flora in the grove mull deposit (Figure 4b.) has characteristics identical to those of deposits assigned to the Eemian interglacial at Evijärvi (Eriksson et al. 1980), Teuva (Niemelä and Tynni 1979) and Pudasjärvi (Sutinen 1984, 1992).

It has been possible to correlate the till stratigraphy of Haapavesi Vesiperä with a large areas in Ostrobothnia. A till stratigraphy strongly resem- bling that of Haapavesi exists at Vimpeli, where the younger basal till bed is underlain by an organic interglacial deposit in situ, and further by a very compact older till bed. The interglacial deposit contains abundant thin tree trunks and branches gnawed through by beavers (Aalto et al. 1989).

Very little is known about deposits of the icefree phases preceding the Eem Interglacial in southern and western Finland, and what is known derives from scattered sources. At Ojanperä, Vihanti in Ostrobothnia, fragments of organic matter, gyttja and peat found in an older till and also a silt deposit overlain by this till have been interpreted as deposited by the Saale glaciation (Kontio 1976, Grönlund et al. 1985, Hirvas \& Nenonen 1987).

The peat and gyttja fragments in a secondary position in the older till at Ojalanperä, Vihanti, and the silt deposit under the till can be considered as interglacial, older than Late-Pleistocene for three reasons: they are in the appropriate lithostratigraphic position; their pollen flora differs from that in the Eem interglacial deposits in Ostrobothnia; and their diatom flora has features suggestive of an 'old age'.

In conjunction with current investigations on the Lappajärvi meteorite crater the stratigraphy and geological evolution of the 74-m-thick Pleistocene deposits in the crater have been studied (Salonen et al. 1992). Sediments and gyttja deposited in water have been found beneath thick Late-Pleistocene tills, at a depth of about $40 \mathrm{~m}$. The diatom flora of the deposit includes abundant communities of diatoms, possibly Tertiary relics. The deposit has not been dated, but the gyttjas and the underlying tills are obviously older than the Eemjan interglacial.

Figure 4A. The pollen diagram of the Haapavesi, Vesiperä section, showing typical Eemian interglacial vegetation in Ostrobothnia (Hirvas \& Nenonen 1987, Figure 4).

B. The pollen diagram (analyzed by Brita Eriksson) of the Vesiperä forest bed, from the thickest mull section. Organic material in the forest bed is rich hazel-alder grove mull soil with flattened spruce twigs and fragments of alder. Both studied sections are from the same test pit just $5 \mathrm{~m}$ apart each other. 
VESIPERÄ

A.
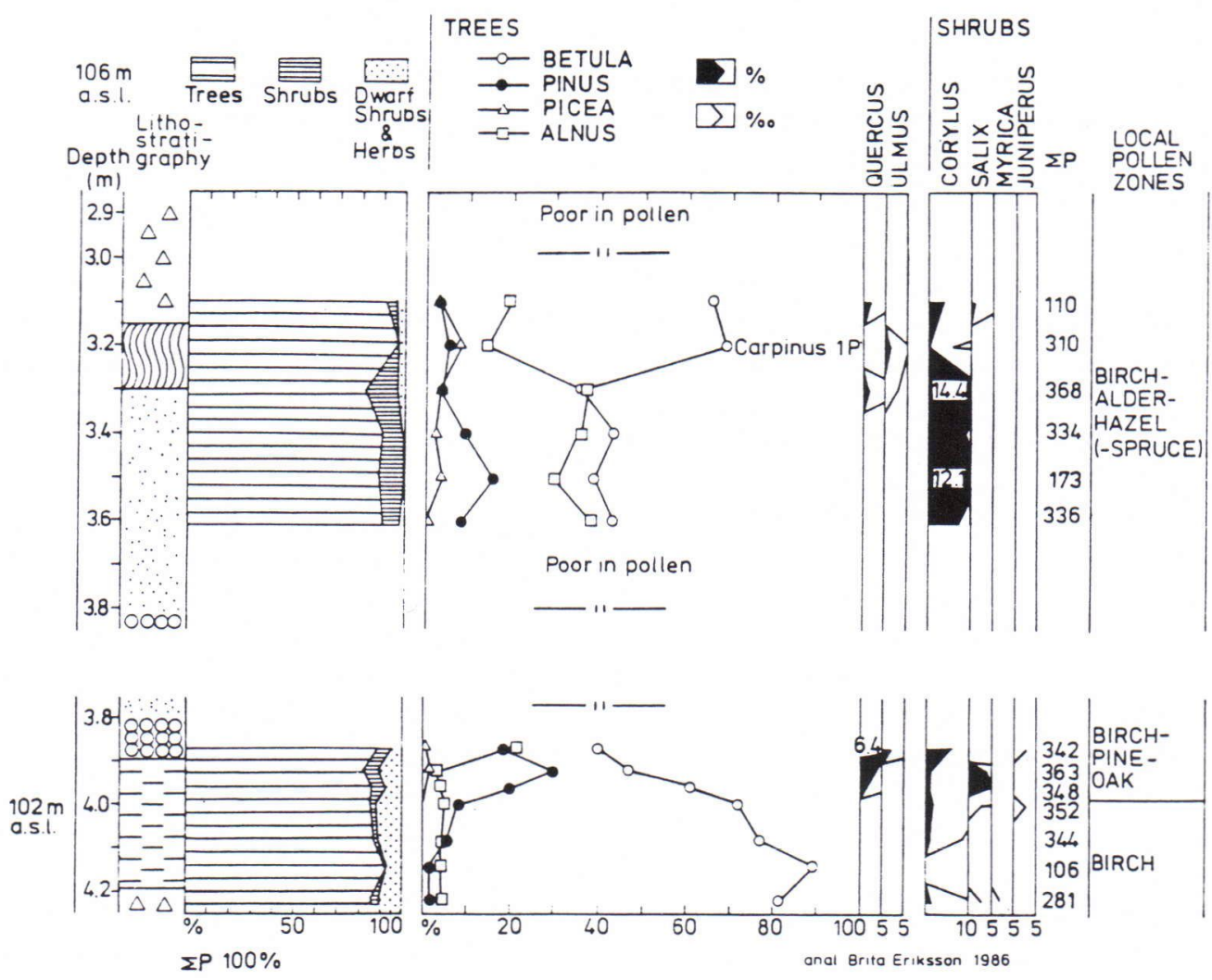

$\Delta \Delta$ TILL $\infty$ GRAVEL $\square$ SAND E- CLAY $\$$ IIIII MULL
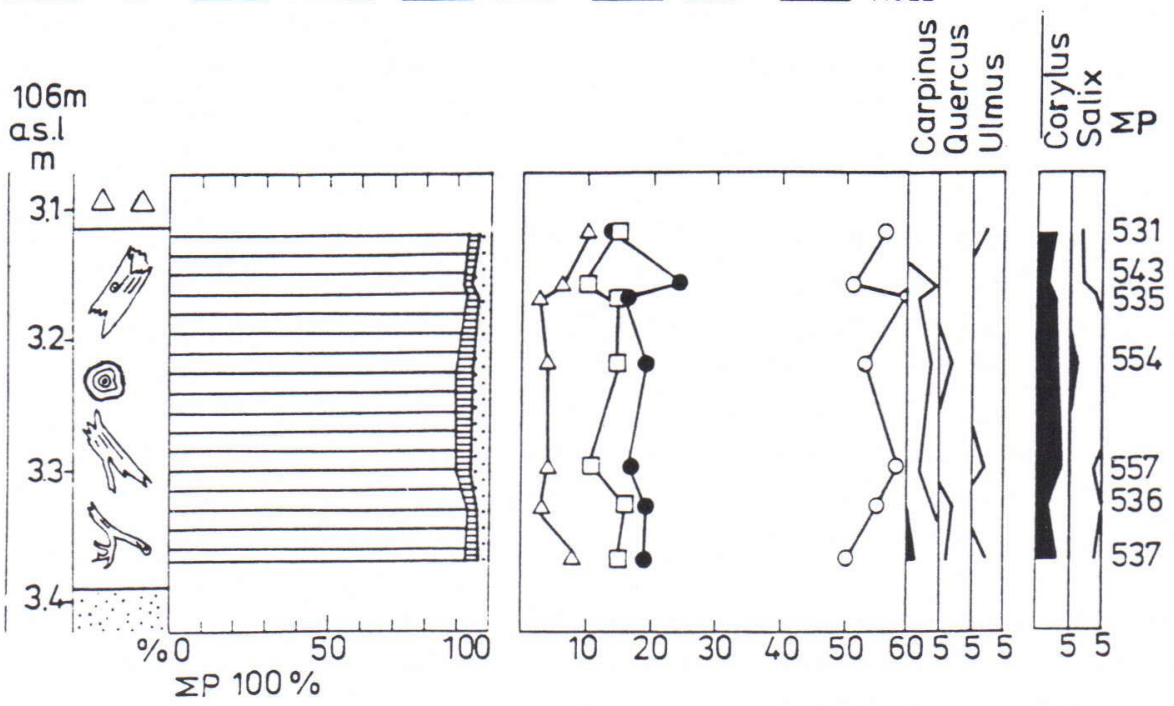

B. 
Salonen and his coworkers suggest that the deposits were formed during the Saalian glaciation and its interstadials.

In summer 1991, a 6-m-thick gyttja deposit underlain by $14 \mathrm{~m}$ of clay and silt was found under Late-Pleistocene till deposits, $20 \mathrm{~m}$ thick, at Virtasalmi, Savo. There are also deep subtill occurrences of kaolin weathering products in the area. Studies on these occurrences brought to light other subtill deposits of fine-grained sediment. The pollen flora of the subtill gyttja deposit at Virtasalmi differs from that of the Eem interglacial deposits. It is probably older than Late-Pleistocene, and may well represent an earlier interglacial.

\section{Discussion and conclusions}

The till stratigraphy of southern and central Finland is to a great extent a deglaciation stratigraphy, in the sense that the ice did not retreat across the region in a single movement but rather would seem to have advanced as large glacial lobes to areas which had once been exposed. This is what have happened at least in the case of the two major ice-marginal formations, the Salpausselkä moraines and the Central Finland formation. Evidence for such an event is seen in the continuation of the surface till bed of the glacial foreland as the lower till bed within the arch of the ice-marginal formation, where it is overlain by varve sediments representing an ice-free phase and a younger till bed deposited by the ice flow in the lobe that terminated in the marginal formation.

The date of the older, very tightly compacted till with a high clay content found in the coastal belt of southern Finland and its correlation with other tills have not been established but current conjecture varies from a date older than the last interglacial, possibly the Saalian, to one younger than the Peräpohjola Interstadial, i.e. the Middle or Late Weichselian.

The results of the investigation indicate that the younger till formations of Western Finland, Ostrobothnia represents the Middle and Late-Weichselian glaciation and the older till formation the Saal- ian glaciation. The till bed III described from Lapland (Hirvas 1991) and older till from Nordkalott area and from Västerbotten Sweden, which represents Early Weichselian glaciation, has not been found in Ostrobothnia. The till-covered marginal formation MZ 1 at Pudasjärvi north of Oulu described by Sutinen (1982, 1984 and 1992) may mark the outermost margin of the Early Weichselian glaciation (Fig. 3).

The lithostratigraphy suggests that Ostrobothnia experienced an ice-free period that included the Eemian interglacial and possibly the Early Weichselian interstadials (Brörup-Peräpohjola-Odderade). Hence the late Quaternary evolution of Ostrobothnia would roughly correspond to the glacial history of Denmark (Sjørring 1983) and southern Sweden (Lundqvist 1983). This would explain why usually only one till bed is encountered above the organic deposits in Ostrobothnia, even though their microfossils may differ greatly from those at the adjacent site. Thus, for example, the deposits at Norinkylä (Niemelä \& Tynni 1979, Grönlund 1991), Evijärvi (Eriksson et al. 1980), Vimpeli (Aalto et al. 1983, 1989), Oulainen (Forsström 1982, 1984), Harrinkangas (Gibbard et al. 1989, Kujansuu et al. 1991), Haapavesi Ollala (Forsström et al. 1987, 1988), Haapavesi Vesiperä (Nenonen 1986, Hirvas \& Nenonen 1987, Nenonen et al. 1991) and Haapavesi Marjamurto (Peltoniemi et al. 1989), Puhos (Sutinen 1984, 1992) may, according to this interpretation, represent the same long ice-free period (Figs. 3 and 5).

Haapalankangas esker at Jurva, Harrinkangas esker at Kauhajoki, Horonpää esker at Teuva and Risåsen esker at Kristiinankaupunki are covered by two till formations deposited by glacier flowing from north and northwest. Interglacial and interstadial deposits and paleosols are also found from the same till covered esker formations (cf. Niemelä and Tynni 1979, Gibbard et al. 1989, Bouchard et al. 1991, Donner 1989, Niemelä and Jungner 1991, Kujansuu et al. 1991) that according to current concepts represent Saalian deglaciation and following Eemian interglacial and Weichselian interglacials and stadials. The nature of above mentioned two till formations is under 


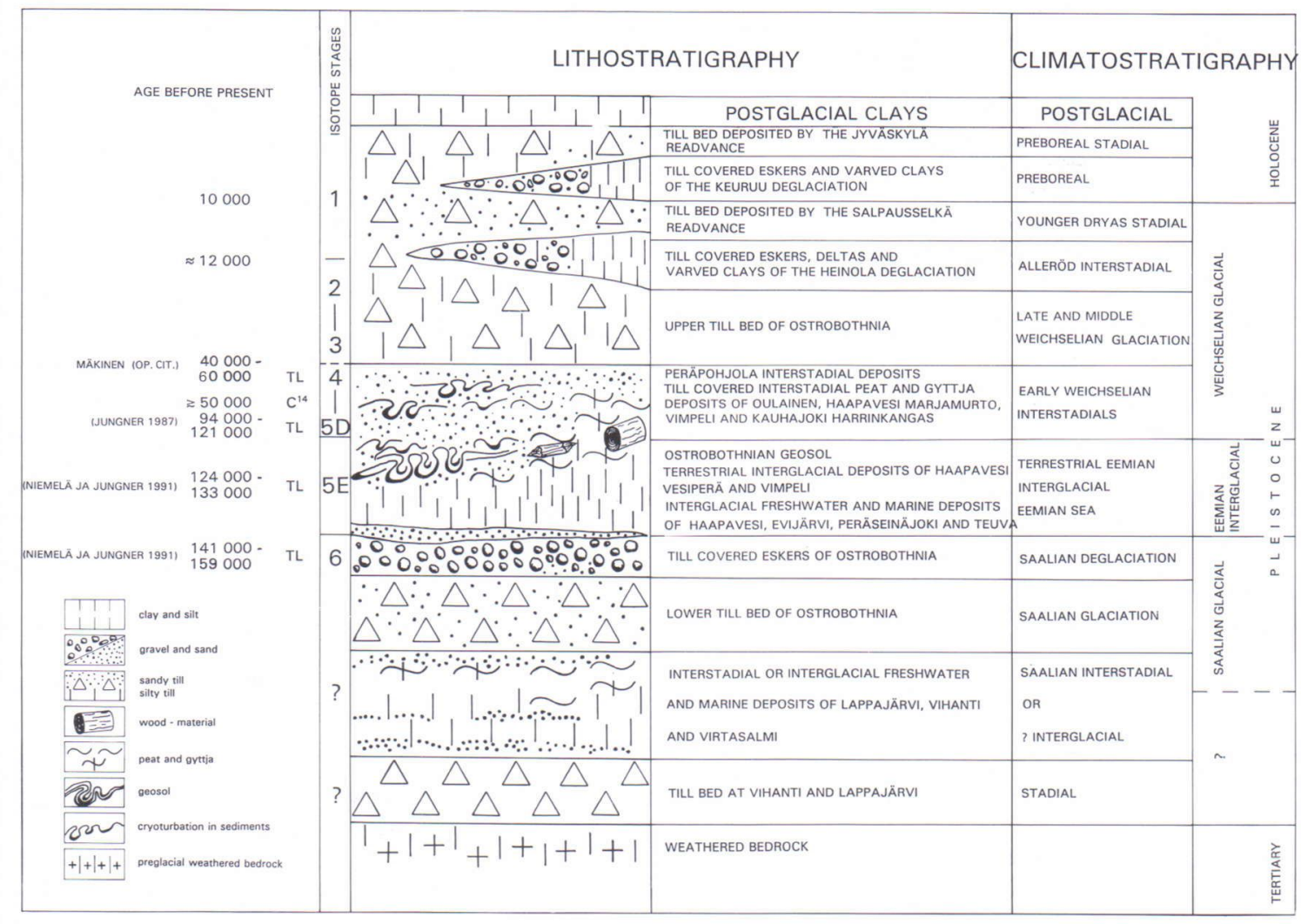

Fig. 5. A Synthesis of the Pleistocene stratigraphy of southern and central Finland.

investigation. Tills may represent Middle and Late Weichselian glaciation and its oscillations but even Early Weichselian glaciation cannot be excluded.

Southern Sweden was covered by a continental ice sheet during the Weichsel glaciation 21000 13000 years ago. Between Eemjan interglacial and the Weichselian interstadials, arctic tundra and polar desert conditions prevailed in southern Sweden (Berglund \& Lagerlund 1981). According to a number of radiocarbon dating from Finland clustering around $40000 \_50000$ years BP (Kankainen \& Huhta 1986) and some TL-dating made from till covered littoral and eolian sediments clustering $40000-60000$ years BP (Kalevi Mäkinen op. cit) it was previously interpreted that continental ice sheet entered western Finland first around 50000 years ago. Radiocarbon dates older than
40000 years are now considered unreliable. Since even minute amounts of young carbon reduce the age of old material by tens of thousands of years, the spread of the ice sheet about 50000 years ago is very uncertain. According to the oceanic oxygen isotope curve the Weichselian continental glacier could have already started to spread 75000 years ago (cf. Andersen and Mangerud 1989, Mangerud 1991).

The fanlike spreading of the flow of the ice sheet, which deposited the Jyväskylä readvance till in Ostrobothnia and the Salpausselkä readvance till demonstrated that, at least in southern Ostrobothnia and Central Finland, till was deposited simultaneously with the ice-marginal formations at about $9700-11000 \mathrm{BP}$. The large glacial lobes that were active during the deglaciation strongly 
abraded the Quaternary formations and deposited till beds on the proximal side of the ice-marginal formations in particular, which hampers the correlation of the till stratigraphy across these formations. Therefore e.g. Punkari $(1984,1989)$ has concluded erroneously that the Finnish till stratigraphy developed in its entirely during the last deglaciation stage as a result of time-transgressive glasiodynamic processes.

At present stage of the study of Pleistocene stratigraphy in southern and western Finland arises need for comprehensive Pleistocene stratotypes. The correlation of Pleistocene formations in Finland and also to neighbouring countries demands well established stratotypes according to accepted stratigraphical procedure (cf. Bouchard et al. 1990). Quaternary profiles from Ostrobothnia, Haapavesi Vesiperä, Peräseinäjoki Viitala and Pyhäjärvi Pyhäsalmi represents possible stratotypes of the Late Pleistocene series. The Quaternary stratigraphy in the areas of the former huge ice lobes of the Scandinavian ice sheet, at Rääkkylä, Heinola and Jyväskylä are good examples of the deglaciation stratigraphy which marks transition from the Pleistocene series to the Holocene series.

\section{References}

Aalto, M., Donner, J., Niemelä J. \& Tynni, R., 1983. An eroded interglacial deposit at Vimpeli, South, Finland. Geological Survey of Finland Bulletin 324, 42 pp.

Aalto, M., Donner, J., Hirvas, H. \& Niemelä, J., 1989. An interglacial beaver dam deposit at Vimpeli, Ostrobothnia, Finland. Geological Survey of Finland Bulletin 348, 34 pp.

Aario, R., 1966. Kieselgur in fluvioglazialen Ablagerungen in Haapajärvi in Ostbottnien. Comptes Rendus de la Société géologique de Finlande 38, 3-30.

Aartolahti, T., 1972. On deglaciation in southern and western Finland. Fennia 114, 84 pp.

Andersen, B. \& Mangerud, J., 1989. The last interglacial-glacial cycle in Fennoscandia. Quaternary International $3 / 4,21-29$.

Berglund, B. \& Lagerlund, E. 1981. Eemian and Weichselian stratigraphy in South Sweden. Boreas 10, 323-362.

Bouchard,M.A.\& Salonen, V-P. 1990. Boulder transport in shield areas. In R. Kujansuu \& M. Saarnisto (eds.), Glacial indicator tracing , 87-107. Rotterdam. Balkema.

Bouchard, M.A., Gibbard,P.\& Salonen, V-P. 1990. Lithosratotypes for Weichselian and pre-Weichselian sediments in southern

\section{Synthesis of Pleistocene stratigraphy in south- ern and western Finland}

The diagram in Fig. 5 presents a synthesis of the Pleistocene stratigraphy of southern and western Finland. The data on Late-Pleistocene lithostratigraphy and geological evolution are fairly comprehensive, whereas those on the Pleistocene deposits in southern Finland predating the Late Pleistocene are still fragmentary. It seems that some occurrences of weathered bedrock and redeposited remains of Tertiary microfossils are all that is left of the Tertiary. Nevertheless, the finds of redeposited microfossils and the promising indications obtained from deep depressions covered with Pleistocene sediments encourage us to expect that more light will be shed on the early history of the Pleistocene in southern Finland in the future.

Acknowledgements. Author wishes to thank Professors J. Mangerud and V-P Salonen for critically reading the manuscript. Author is greateful to Dr H. Hirvas, Dr T. Grönlund, B. Eriksson, P. Huhta, L. Ikonen, T. Kankainen and P. Hakala of Geological Survey of Finland for their enthusiastic cooperation and help in the study of the Pleistocene stratigraphy of southern and western Finland. and western Finland. Bulletin of the Geological Society of Finland, 62(1), 79-95.

Donner, J. 1983. The identification of Eemian interglacial and Weichselian interstadial deposits in Finland. Annales Acadmiae Scientiarum Fennicae A. III 136, 38 pp.

Donner, $J$. 1988. The Eemian site of Norinkylä compared with öother interglacial and interstadial sites in Ostrobothnia, western Finland. Annales Academiae Scientiarum Fennicae A III 149, 31 pp.

Donner, J., Jungner, H. \& Kurten, B. 1979. Radiocarbon dates of mammoth finds in Finland compared with radiocarbon dates of Weichselian and Eemian deposits. Bulletin of the Geological Society of Finland 51, 45-54.

Eriksson, B., Grönlund, T. \& Kujansuu, R. 1980. Interglasiaalikerrostuma Evijärvellä Pohjanmaalla. Summary, An interglacial deposit at Evijärvi in the Pohjanmaa region, Finland. Geologi 32, 65-71.

Forsström, L. 1982. The Oulainen interglacial in Ostrobothnia, western Finland. Acta Universitatis Ouluensis. Series A 136 Geol, 123 p.

Forsström, L. 1984. Eemian and Weichselian correlation problems in Finland. Boreas, 13, 310-318. 
Forsström, L., Aalto, M., Eronen, M. \& Grönlund, T. 1988. Stratigraphic evidence for Eemian öcrustal movements and relative sea-level changes in Eastern Fennoscandia. Palaeogeography, Palaeoclimatology, Palaeoecology 68, $317-335$.

Forsström, L., Eronen, M. \& Grönlund, T. 1987. On marine phases and shore levels of the Eemian interglacial and Weichselian interstadials on the coast of Ostrobothnia , Finland. Geological Survey of Finland. Special Paper 2,37-42.

Gibbard, P., Forman, S., Salomaa, R., Alhonen, P., Jugner, H., Peglar, S., Suksi, J. \& Vuorinen, A. 1989. Late Pleistocene stratigraphy at Harrinkangas, Kauhajoki, western Finland. Annales Acadmiae Scientiarum Fennicae A. III 150, 36 pp.

Grönlund, T. 1991. The diatom stratigraphy of the Eemian Baltic Sea on the basis of sediment discoveries in Ostrobothnia, Finland. Geological Survey of Finland, Report of Investigation 102, 26 pp.

Grönlund, T., Hirvas, H., Ikonen, L. \& Nenonen, K. 1985. Ojalanperä, Vihanti, Fragments of organic material within an older till bed. In M. Saarnisto (ed.) INQUA till symposium. Field workshop August 20-29, 1985, Excursion guide. Geological Survey of Finland, Department of Quaternary Geology., Espoo, p. 83-89.

Hirvas, H. 1991. Pleistocene stratigraphy of Finnish Lapland. Geological Survey of Finland, Bulletin 354, 123.

Hirvas, H.\& Nenonen, K. 1987. The Till stratigraphy of Finland. In Kujansuu, R. \& Saarnisto, M. (eds.), INQUA till symposium Finland 1985. Geological Survey of Finland Special Paper $3,49-93$.

Hууррӓ, E. 1966. Salpausselän geologinen rakenne Lahden seudulla. Summary, on the structure of the First Salpausselkä at Lahti. Geologi 18, 73-76.

Ignatius, H. \& Leskelä, S. 1970. Intergstadiaalinen tai interglasiaalinen kerrostuma Nivalan Hiturassa. Summary, An interstadial or interglacial deposit in Hitura, Nivala, westcentral Finland. Geologi 22, 61-64.

Jungner, H. 1987. Thermoluminescence dating of sediments from Oulainen and Vimpeli. Boreas 16, 231-235.

Kankainen, T. \& Huhta, P. 1986. Om åldern på Organiska avlagringar under morän i Finland (in Swedish). In Abstratcs of 17e Nordiska Geologmötet 1986, Helsingfors Univ 12.15. 5. 1986. p. 67. Helsinki.

Kontio, M. 1976. Tiedonanto moreeninalaisesta orgaanisesta aineksesta Vihannin karttalehdellä 2434, with english summary. Geologi 28, 89-90.

Kujansuu, R. \& Nenonen, K. 1987. Till stratigraphy and ice-flow direction in North Karelia. Geogical Survey of Finland Special Paper 1, 59-66.

Kujansuu, R., Saarnisto, M., Räisänen, M-L. \& Hansel, A. 1991. Fossil soil of Kärjenkoski and its correlatives in Ostrobothnia, western Finland. Geological Survey of Finland, Special Paper $12,119-126$.

Liivrand, E. 1984. The interglacials of Estonia. Annales Acadmiae Scientiarum Fennicae A. III 138, 5-16.

Lundqvist, J. 1983. The glacial history of Sweden. In J. Ehlers (ed.), Glacial Deposits in North-West Europe, 77-82. Rotterdam, Balkema.
Mangerud, J. 1991. The Scandinavian ice-sheet through the last interglacial/glacial cycle. Paläoklimaforschnung,Volume 1. pp. 307-338. Stuttgart, Fischer.

Nenonen, K. 1986. Orgaanisen aineksen merkitys moreenistratigrafiassa. Summary, The significance of organic material in till stratigraphy. Geologi 38, 41-44.

Nenonen, K.,Eriksson, B.\& Grönlund,T. 1991 The till stratigraphy of Ostrobothnia, western Finland, with reference to new Eemian interglacial sites. In Andersen, B. P. \& Königsson, L.$K$. (ed), Late Quaternary Stratigraphy in the Nordic Countries 150000 - 15000 B.P. Striae 34, pp. 65-76.

Niemelä, J. \& Jungner, H. 1991. Thermoluminescence dating og late Pleistocene sediments related to till-covered eskers from Ostrobothnia, Finland. Geological Survey of Finland, Special Paper 12, 135-138.

Niemelä,J.\& Tynni, R. 1979. Interglacial and Interstadial sediments in the Pohjanmaa region, Finland. Geological Survey of Finland Bulletin 302, 42 p.

Okko, M., 1962. On the development of the First Salpausselkä, west of Lahti. Bulletin de commission géologique Finlande $202,1-162$.

Peltoniemi, H., Eriksson, B., Grönlund, T. \& Saarnisto, M. 1989. Marjamurto, an interstadial site in an till covered esker area of central Ostrobothnia, western Finland. Bulletin of the geological Society of Finland 61 (2), 209-237.

Punkari, M. 1984. The relations between glacial dynamics and tills in the eastern part of the Baltic Shield. Striae 20, 49-54.

Punkari, M. 1989. Glacial dynamics and related erosion-deposition processes in the Scandinavian ice sheet in south-west Finland, a remote sensing, fieldwork and computer modelling study. Final Report, Project 01/663, Research Council for the Natural Sciences, Academy of Finland, pp. $1-86$.

Rainio, H. 1985. Första Salpausselkä utgör randzonen för en landis som avancerat pönytt. Summary The First Salpausselkä is a marginal formation of the outermost margin of a readvanced ice sheet. Geologi $37(4-5), 70-77$.

Rainio, H. 1991. The Younger Dryas ice marginal Formations of Southern Finland. In Rainio, H \& Saarnisto, M. (eds.) 1991. IGCP PROJECT 253, Termination of the Pleistocene. Eastern Fennoscandia Younger Dryas End Moraines. Field conference North Karelia, Finland and Karelian ASSR, June 26.July 4, 1991. Geological Survey of Finland Guide 32, 25-72.

Rainio, H.\& Lahermo, P. 1976. Observations on dark grey basal till in Finland. Bulletin of the Geological Society of Finland, $48,137-152$.

Rainio, H.\& Lahermo, P. 1984. New aspects on the distribution and origin of the so called dark till. Striae 20, 45- 47.

Rainio, H, Kejonen, A., Kielosto, S. \& Lahermo, P. 1986. Avancerade inlandisen på nytt också till Mellanfinska randformationen? Summary, Is the Central Finland ice marginal formation terminal? Geologi 38 (4-5), 95-109.

Repo, R. 1957. Untersuchnungen über die Bewegungen des Inlandeises in Nordkarelien. Geological Survey of Finland, Bulletin $179,1-178$.

Salonen, V-P.\& Glückert (in press), G. Late-Weichselian activity and sediments in southwestern Finland. Sveriges Geologiska Undersökning, Serie A. 
Salonen, V-P., Eriksson, B.\& Grönlund, T. 1992 A long sequence of Pleistocene strata from the Lappajärvi meteorite crater in Ostrobothnia, western Finland. Boreas, 21, 253-269.

Sjürring, S., 1983, The glacial history of Denmark. In J. Ehlers (ed.). Glacial deposits in north-western Europe. pp. 163 168. Rotterdam, Balkema.

Sutinen, R. 1982. Glasiaalistratigrafiasta Pudasjärven alueella Peräpohjolassa. Summary, On glacial stratigraphy in Pudasjärvi area, Peräpohjola. Geologi 34 (9-10), 191-195.
Sutinen, R. 1984. On the Glacial Stratigraphy in Pudasjärvi Area. Striae 20, 91-94.

Sutinen, $R, 1992$. Glacial deposits, their electrical properties and surveying by image interpretation and ground penetrating radar. Geological Survey of Finland, Bulletin 359. 123 p.

Received July 13, 1992

Revision accepted September 29, 1992 